\title{
Article \\ A Hybrid Microbial-Enzymatic Fuel Cell Cathode Overcomes Enzyme Inactivation Limits in Biological Fuel Cells
}

\author{
John Parker Evans ${ }^{1}$, Dominic F. Gervasio ${ }^{2, *}$ and Barry M. Pryor ${ }^{3}$ \\ 1 Department of Mechanical and Aerospace Engineering, The Ohio State University, \\ Columbus, OH 43210, USA; evans.2154@osu.edu \\ 2 Department of Chemical and Environmental Engineering, University of Arizona, Tucson, AZ 85721, USA \\ 3 Department of Plant Sciences, Division of Plant Pathology, University of Arizona, Tucson, AZ 85721, USA; \\ bmpryor@arizona.edu \\ * Correspondence: gervasio@email.arizona.edu; Tel.: +1-520-621-6048
}

check for updates

Citation: Evans, J.P.; Gervasio, D.F.; Pryor, B.M. A Hybrid

Microbial-Enzymatic Fuel Cell Cathode Overcomes Enzyme Inactivation Limits in Biological Fuel Cells. Catalysts 2021, 11, 242. https://doi.org/10.3390/ catal11020242

Academic Editor: Barbara Mecheri Received: 1 December 2020

Accepted: 6 February 2021

Published: 11 February 2021

Publisher's Note: MDPI stays neutral with regard to jurisdictional claims in published maps and institutional affiliations.

Copyright: (c) 2021 by the authors. Licensee MDPI, Basel, Switzerland. This article is an open access article distributed under the terms and conditions of the Creative Commons Attribution (CC BY) license (https:// creativecommons.org/licenses/by/ $4.0 /)$.

\begin{abstract}
The construction of optimized biological fuel cells requires a cathode which combines the longevity of a microbial catalyst with the current density of an enzymatic catalyst. Laccasesecreting fungi were grown directly on the cathode of a biological fuel cell to facilitate the exchange of inactive enzymes with active enzymes, with the goal of extending the lifetime of laccase cathodes. Directly incorporating the laccase-producing fungus at the cathode extends the operational lifetime of laccase cathodes while eliminating the need for frequent replenishment of the electrolyte. The hybrid microbial-enzymatic cathode addresses the issue of enzyme inactivation by using the natural ability of fungi to exchange inactive laccases at the cathode with active laccases. Finally, enzyme adsorption was increased through the use of a functionally graded coating containing an optimized ratio of titanium dioxide nanoparticles and single-walled carbon nanotubes. The hybrid microbial-enzymatic fuel cell combines the higher current density of enzymatic fuel cells with the longevity of microbial fuel cells, and demonstrates the feasibility of a self-regenerating fuel cell in which inactive laccases are continuously exchanged with active laccases.
\end{abstract}

Keywords: oxygen reduction reaction; multi-functional catalysts for ORR; bioelectrocalysis; biocathodic microbial communities; optimization of catalyst layers and electrode design

\section{Introduction}

Biological fuel cells (BFCs) use bioderived fuels and catalysts to produce electricity [1]. Most BFCs utilize the oxygen reduction reaction at the cathode, thus BFCs can be categorized by the type of catalyst used at the cathode: (I) metal catalysts, (II) enzymatic catalysts, and (III) microbial catalysts [2-4]. Platinum-group metal catalysts are most common due to their superb catalytic properties, but the high price of the catalysts prevents the large-scale adoption of biological fuel cells [5]. Enzymatic catalysts hold promise to replace metal catalysts, but suffer from short lifetimes and mass transport limitations [3,4,6,7]. Microbial fuel cells rectify the short lifetimes of enzymatic catalysts at the expense of additional mass transport limitations and lower current densities [2,8-10]. The construction of optimized biological fuel cells requires a cathode which combines the longevity of a microbial catalyst with the current density of an enzymatic catalyst [11,12].

Laccases are commonly used enzymatic catalysts in biological fuel cell cathodes because they demonstrate reversible adsorption to carbon electrodes and an ability to directly transfer electrons to carbon nanotubes [13-15]. Laccases catalyze the one-electron oxidation of diverse chemical substrates at a single-copper-containing site near the surface of the protein [16,17]. Concomitantly, laccases catalyze the four-electron reduction of dioxygen to water $[17,18]$ at a tri-copper site in the interior of the protein, without the production of superoxides or peroxides [19]. 
Substrate Oxidation Reaction

$$
4 \text { Substrate } \text { RED }^{R}-4 e^{-}+\text {laccase }^{O X} \longrightarrow \text { laccase }^{R E D}+4 \text { Substrate } e^{O X}+4 H^{+}
$$

Oxygen Reduction Reaction

$$
\text { laccase }^{R E D}+4 e^{-}+\mathrm{O}_{2}+4 \mathrm{H}^{+} \longrightarrow \text { laccase }^{\mathrm{OX}}+2 \mathrm{H}_{2} \mathrm{O}
$$

The current body of research establishes that laccase cathodes suffer from current density losses attributable to short enzyme lifetimes, suboptimal enzymatic reaction velocities, enzyme inactivation, and low enzyme adsorption [20-23]. In order to mitigate these deficiencies, attempts have been made to engineer laccases with faster reaction velocities [24-30]. However, few studies have investigated strategies to mitigate current density losses from these other factors [31,32]. In previous work, laccase cathode lifetimes were extended by the periodic exchange of laccase-containing electrolytes without the enzymeproducing microbe in the electrode [22,23]. To advance research in this area, filamentous fungi and rational cathode design can be used to overcome short enzyme lifetimes, enzyme inactivation, and low enzyme adsorption. Fungi secrete laccases to catalyze the breakdown of lignin in the normal metabolism [16,33,34]. Fungi naturally address the problem of laccase inactivation via specialized endocytic pathways which facilitate the absorption of inactive enzymes for breakdown and reuse [21-23,33].

This work presents a hybrid microbial-enzymatic cathode leveraging fungal metabolism to overcome short enzyme lifetimes, enzyme inactivation, and low enzyme adsorption associated with pure laccase cathodes (Figure 1). Five different filamentous fungi were screened for their ability to produce extracellular laccases. Three inducers were analyzed to maximize laccase secretion while maintaining the medicinal and/or nutritional value of the resulting fungal biomass. To increase enzyme loading at the cathode, a functionally graded coating was applied to the cathode prior to introducing the fungus. The laccase-secreting fungus was grown directly on the coated cathode and the exchange of inactive enzymes with active enzymes was monitored electrochemically.

a

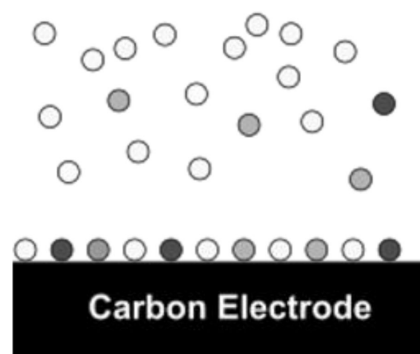

b

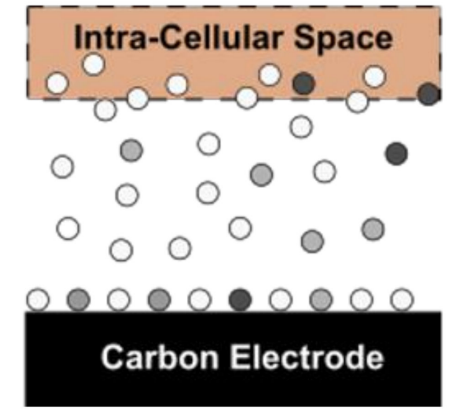

\section{C}

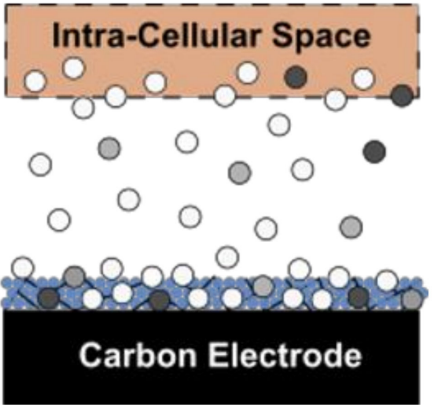

Figure 1. Illustration of (a) bare carbon electrode with no fungus incorporated and no functionally graded coating to increase laccase loading, (b) bare carbon electrode with laccase recycling fungus incorporated but no functionally graded coating, and (c) bare carbon electrode with laccase recycling fungus incorporated and an optimized functionally graded coating to increase laccase loading. The black structures represent the carbon electrode and carbon nanotubes (in functionally graded coating), blue circles represent $\mathrm{TiO}_{2}$ nanoparticles, white circles represent fully active laccase, light grey circles represent partially active laccase, and dark grey circles represent inactive laccase. The orange region indicates the fungal cytoplasm and the dashed line represents the semipermeable membrane of the fungus.

\section{Results}

\subsection{Assessment of Laccase Secretion}

The abilities of five different fungi to secrete enzymatically active laccases were compared with and without induction (Figure 2). In the absence of a laccase-inducing substance, all tested fungi produced less than $10 \mathrm{U} \cdot \mathrm{mL}^{-1}$ of laccase. When copper sulfate, a common 
laccase inducer, was added, all fungi increased the amount of extracellular laccase. In $200 \mathrm{~mL}$ culture bottles, the Pleurotus ostreatus cultures demonstrated the highest extracellular laccase activity. The genetic differences between the subspecies of P. ostreatus had a notable effect on extracellular laccase production, with the commercial strain P. ostreatus N001 producing the least active extracellular laccases on day 4 and the in-house cultured P. ostreatus White producing the highest.

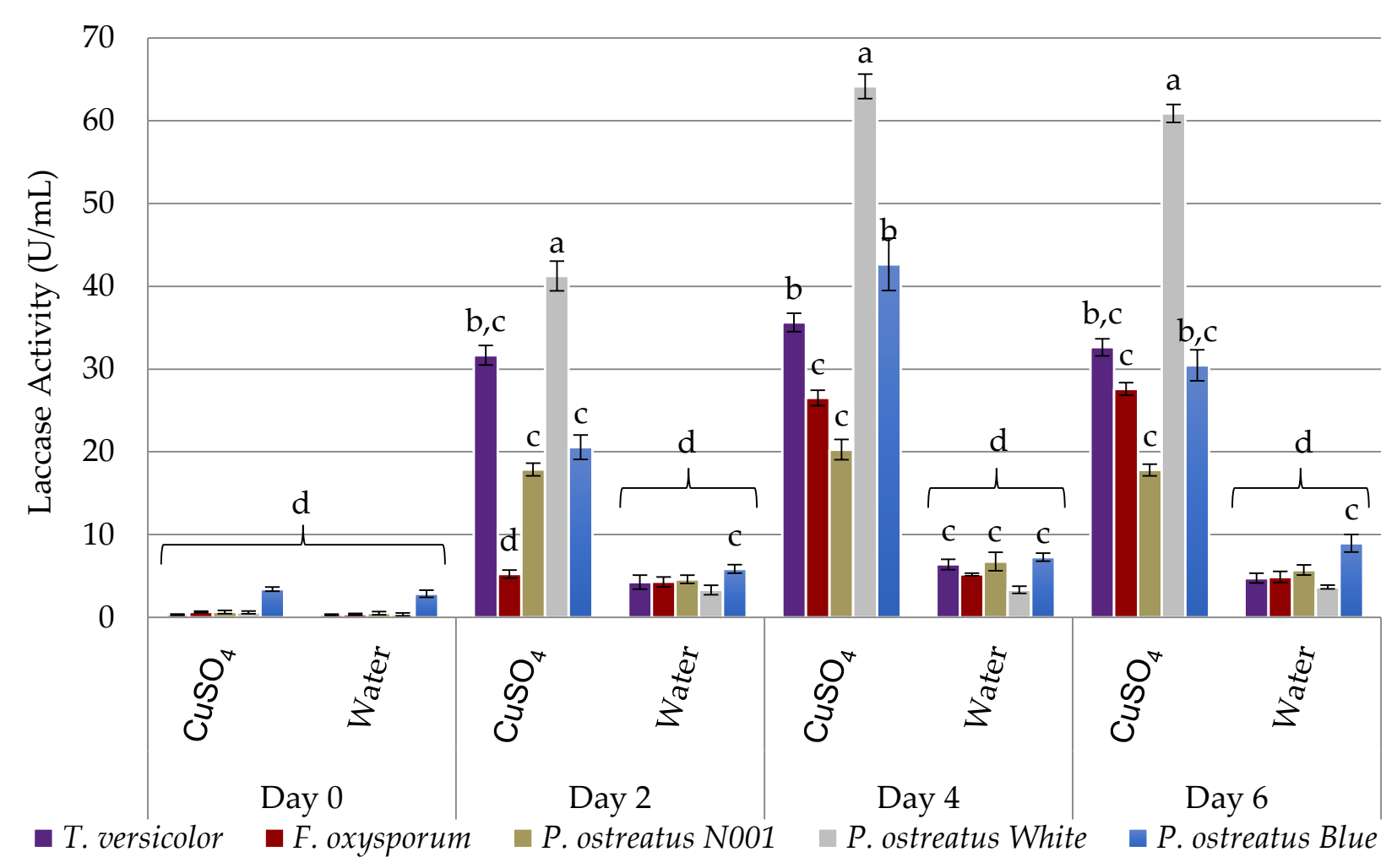

Figure 2. Five different fungi were screened for their ability to produce laccase. Means that do not differ from $P$. ostreatus White grown for 4 days after induction with $\mathrm{CuSO}_{4}$ by a $p$-value of 0.05 are annotated with "a". Means that do not differ from P. ostreatus Blue grown for 4 days after induction with $\mathrm{CuSO}_{4}$ by a $p$-value of 0.05 are annotated with " $\mathrm{b}$ ". Means that do not differ from P. ostreatus Blue grown for 2 days after induction with $\mathrm{CuSO}_{4}$ by a $p$-value of 0.05 are annotated with " $c$ ". Means that do not differ from $P$. ostreatus Blue measured immediately after induction with $\mathrm{CuSO}_{4}$ by a $p$-value of 0.05 are annotated with " $\mathrm{d}$ ".

When smaller reaction vessels $(20 \mathrm{~mL})$ were compared to larger reaction vessels (200 mL), Fusarium oxysporum and Trametes versicolor produced extracellular laccases with the highest activity (Figure 3). The high activities of the extracellular laccases produced by F. oxysporum are likely due to F. oxysporum's role as a plant pathogen [35,36], while the high activity of the cellular laccases produced by the T. versicolor and the P. ostreatus strains can be attributed to their roles as lignin-degrading saprotrophs [36,37]. Despite the ecological relevance of laccases to all tested species [36], it remains unclear why smaller culturing vessels significantly improved the activity of the secreted laccases in the F. oxysporum and $T$. versicolor cultures, while having less of an influence over P. ostreatus cultures. While the mechanism for this is unclear, it may be related to the ability of laccases to degrade phenolic compounds that arrest fungal growth [38]. The $20 \mathrm{~mL}$ setup was used for all subsequent studies, as it provided higher laccase activity, enough biomass for analysis, and was more manageable for subsequent trials. 


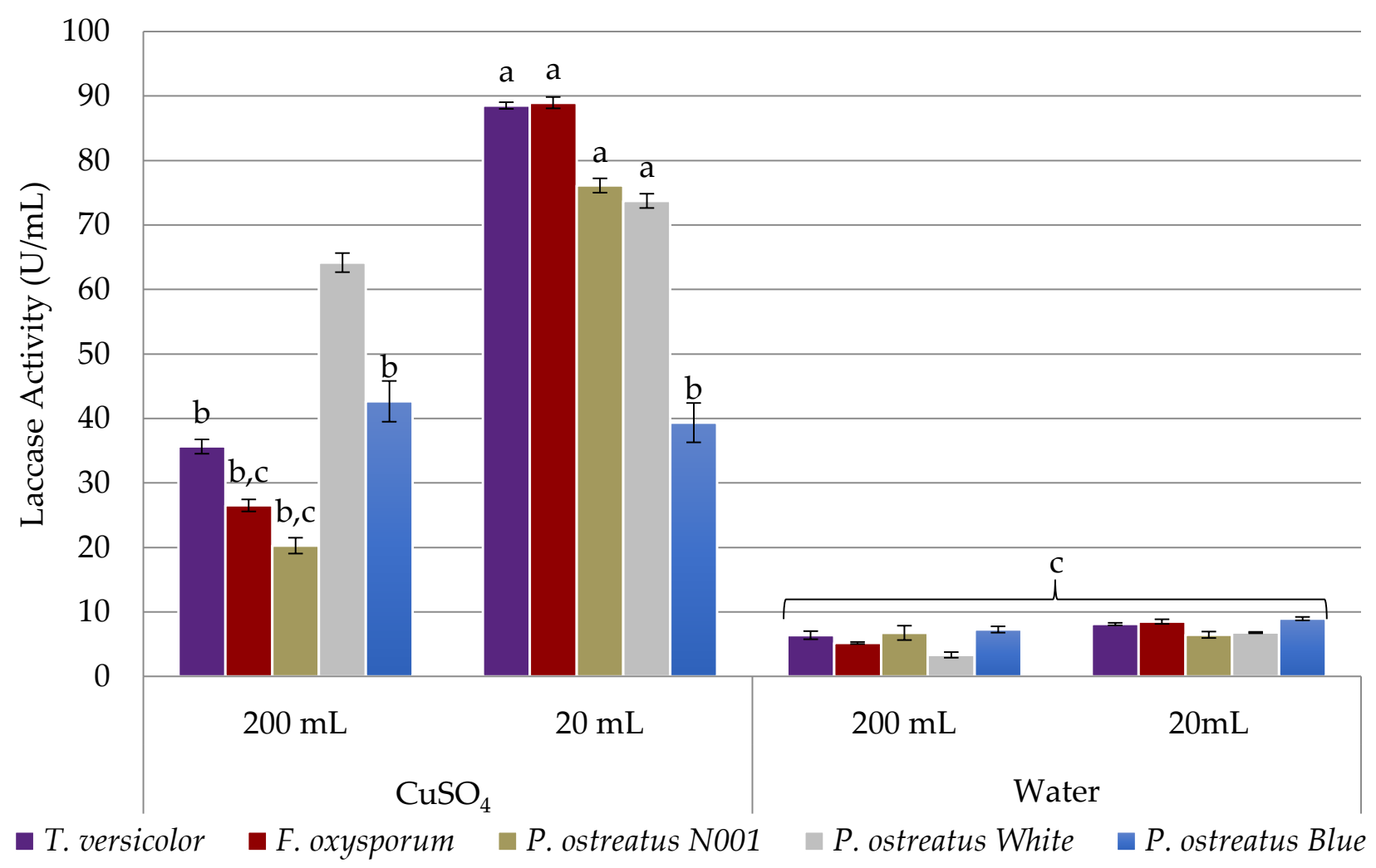

Figure 3. Laccase induction was compared between large and small culture vessels. Means that do not differ from T. versicolor induced with $\mathrm{CuSO}_{4}$ grown in $20 \mathrm{~mL}$ reaction vessels by a $p$-value of 0.05 are annotated with "a". Means that do not differ from T. versicolor induced with $\mathrm{CuSO}_{4}$ grown in $200 \mathrm{~mL}$ reaction vessels by a $p$-value of 0.05 are annotated with " $\mathrm{b}$ ". Means that do not differ from T. versicolor induced with water grown in $200 \mathrm{~mL}$ reaction vessels by a $p$-value of 0.05 are annotated with "c".

Inducing Laccase Secretion with a Biocompatible Inducer

Trametes versicolor has medicinal properties that make the biomass a useful byproduct of this biological fuel cell [39]. The use of copper sulfate as an inducer leads to concerns of heavy metal sequestration by $T$. versicolor, precluding its use for medicinal purposes. We explored Tween 20 as an alternative laccase inducer, as the detergent causes oxidative stress to the fungus and is non-toxic to humans and animals.

When copper sulfate, Tween20, and a mixture of the two were compared, it was discovered that the mean of extracellular laccase activity was not significantly higher in copper sulfate-induced cultures than in Tween20-induced cultures for any tested fungus (Figure 4). This experiment did not detect any evidence against the use of Tween 20 as a laccase inducer that does not contaminate edible or medicinal biomass with heavy metal inducers. No significant differences between biomass were observed between any of the treatments. Despite the absence of heavy metal contamination in Tween20-induced cultures, copper sulfate was chosen as the inducer for subsequent studies because proteomics is needed to provide a deeper insight into the mechanistic differences between crude filtrate and pure laccases in fuel cell cathodes. Tween 20 can cause signal loss in proteomic characterization, and contaminates the mass spectrometry instruments used in proteomics. 


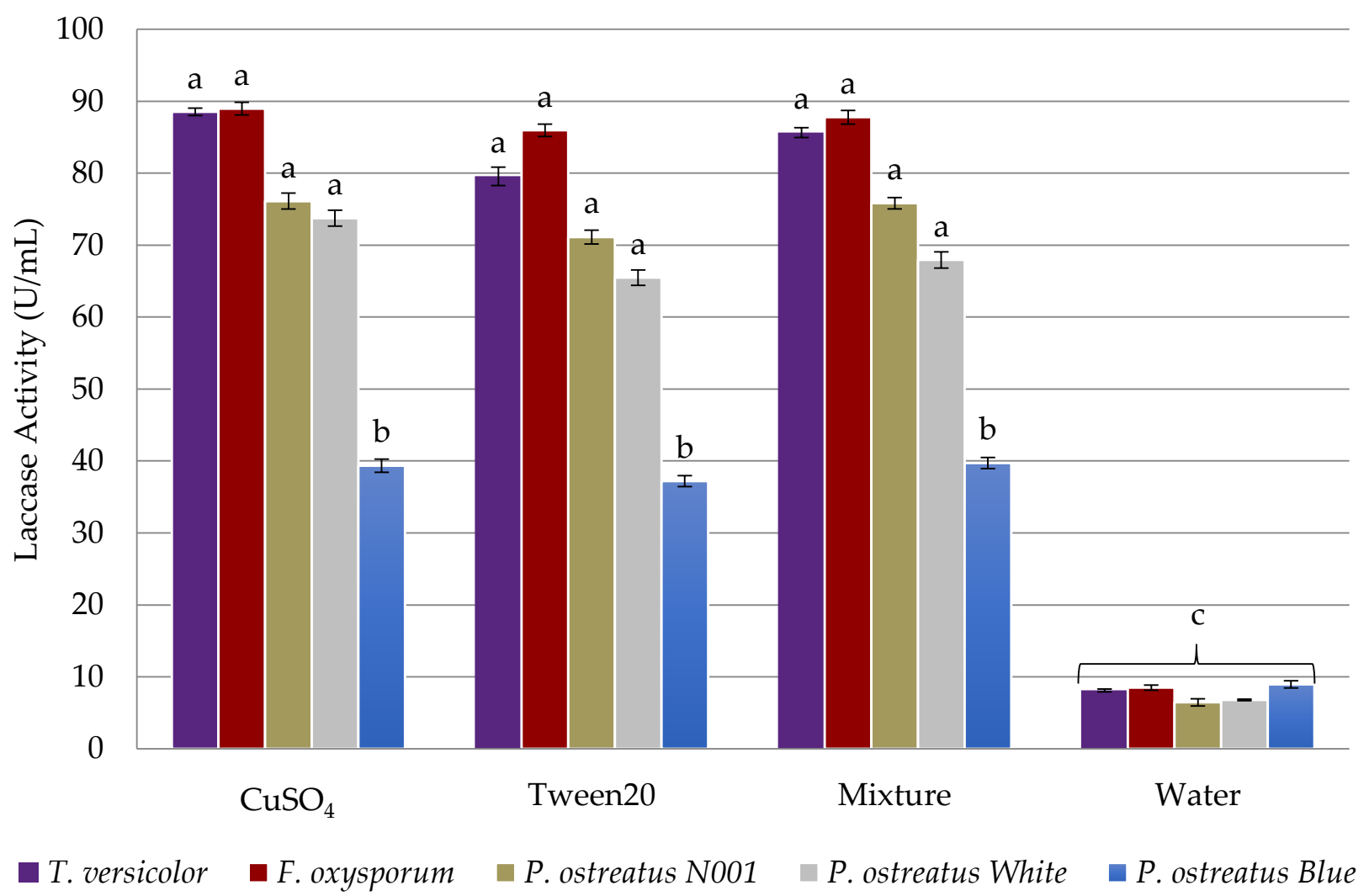

Figure 4. Three laccase inducers, copper sulfate, Tween20 and a mixture of copper sulfate and Tween20, were compared to assess the viability of harvesting the fungal biomass of T. versicolor and P. ostreatus for secondary applications. Means that do not differ from P. ostreatus N001 induced with $\mathrm{CuSO}_{4}$ by a $p$-value of 0.05 are annotated with "a". Means that do not differ from $P$. ostreatus Blue induced with $\mathrm{CuSO}_{4}$ by a $p$-value of 0.05 are annotated with " $\mathrm{b}$ ". Means that do not differ from $P$. ostreatus N001 induced with water by a $p$-value of 0.05 are annotated with " $c$ ".

\subsection{Trametes Versicolor Secretome Analysis}

The secretome of $T$. versicolor was analyzed for protein composition under copper sulfate induction and compared to an uninduced culture. Of particular interest are laccases, peroxidases and proteases. Laccases facilitate the four-electron reduction of oxygen to water [18], while peroxidases facilitate the two-electron reduction of oxygen to peroxide [17], which can kill the fungus [40] and inactivate functional laccases [41]. Proteases hydrolyze the peptide bonds between amino acids in a protein, rendering the protein inactive and the amino acids useable for metabolism or protein synthesis [42].

Copper sulfate induction raised the laccase composition of the secretome $21 \%$, from $33 \%$ to $54 \%$ (Figure 5). Additionally, the peroxidase composition of the secretome was decreased by $8 \%$, to $14 \%$ of total protein. Proteases were not found in abundance in the uninduced culture, but comprised $1 \%$ of the total protein in the copper sulfate-induced culture. The small number of proteases supports our hypothesis that T. versicolor is able to break down and recycle inactive laccases in situ, without disturbing active laccases at the electrode surface. In addition to the proteins of interest, glucose oxidase and glycosidase enzymes were detected in the T. versicolor secretome. These metabolic enzymes do not prohibit the laccase function at the cathode, but can occupy sites otherwise usable by laccases for oxygen reduction [43]. 


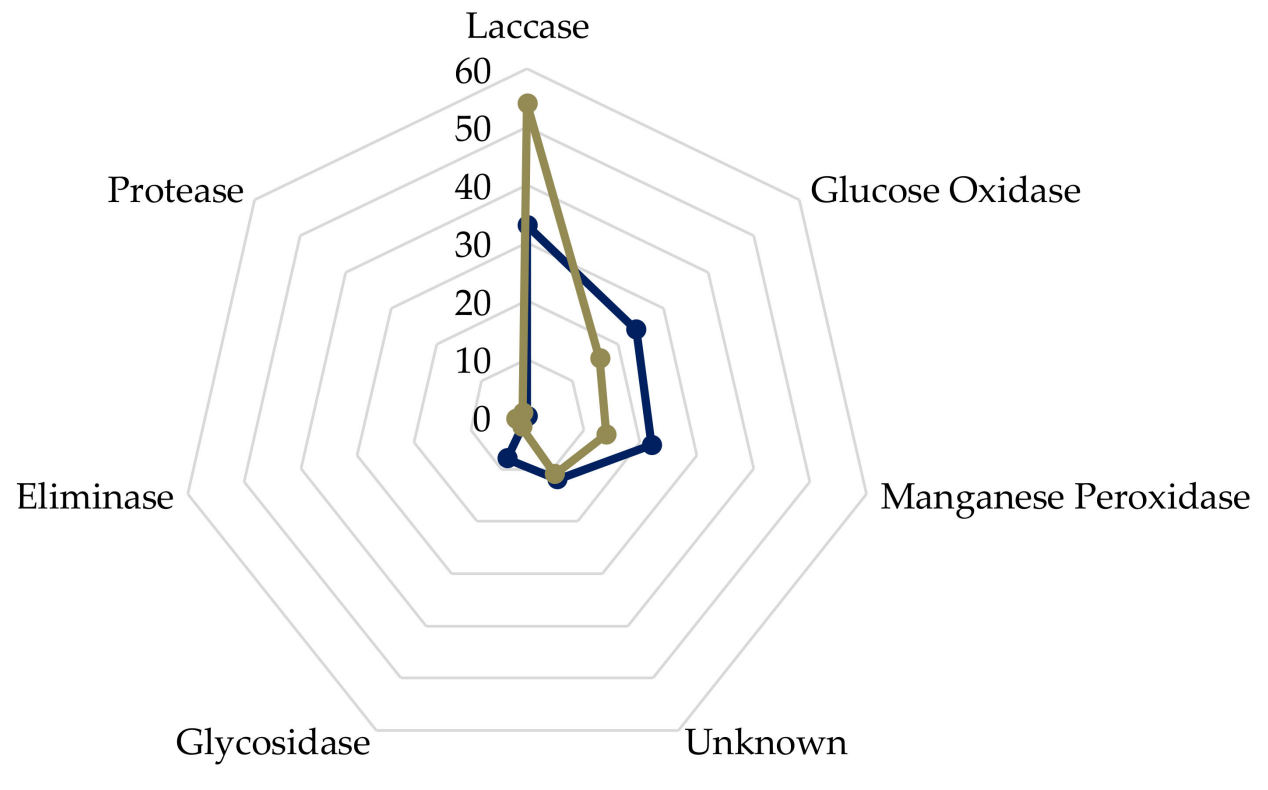

$\longrightarrow \%$ Spectral Counts - Uninduced $\quad \longrightarrow \%$ Spectral Counts - Induced

Figure 5. Radar plot of the composition of the of T. versicolor secretome under standard (blue) and copper sulfate-induced conditions (orange).

\subsection{Comparison of Electrode Coatings}

The carbon cathodes used in this study do not provide a large enough surface area to demonstrate an increase in current density due to the recycling of laccase at the cathode. We therefore developed a functionally graded cathode coating with the goal of improving enzyme loading on the cathodes, while facilitating the time-dependent change of active laccases adsorbed onto the electrode. The coating was composed of titanium dioxide nanoparticles $\left(\mathrm{TiO}_{2}\right)$ to increase porosity [44], carbon nanotubes to increase the electrical conductivity of the coating [45], and Nafion to favorably orient laccase adsorption towards the composite coating [46]. Choi et al. showed that adding carbon nanotubes to the Nafion- $\mathrm{TiO}_{2}$ mixture improved response time, sensitivity, and long-term stability in glucose oxidase-based biosensors [47]. Water was used as a negative control to account for any structural changes to the electrodes during the coating process; an open circuit potential of $52 \mathrm{mV}$ vs. SCE was measured. An optimized ratio of $0.2 \%$ titanium dioxide nanoparticles to $0.7 \%$ carbon nanotubes ( $w: w$ ) was found to increase the open circuit potential from $52 \mathrm{mV}$ vs. SCE (water coating) to $584 \mathrm{mV}$ vs. SCE (Table 1 and Figure 6).

Table 1. Summary of the different coating compositions designed to increase laccase loading at the cathode, their open circuit potentials ( $\mathrm{mV}$ vs. SCE) and current density at $-200 \mathrm{mV}$ vs. SCE $\left(\mathrm{mA} \cdot \mathrm{cm}^{-2}\right)$.

\begin{tabular}{ccc}
\hline Coating Composition & $\begin{array}{c}\text { Open Circuit Potential } \\
(\mathbf{m V} \text { vs. SCE) }\end{array}$ & $\begin{array}{c}\text { Current Density at }-\mathbf{2 0 0 ~ m V} \\
\text { vs. SCE }\end{array}$ \\
\hline $0.9 \% \mathrm{TiO}_{2}$ & 128.0 & -68 \\
\hline $0.7 \% \mathrm{TiO}_{2}-0.2 \% \mathrm{CNT}$ & 134 & -152 \\
\hline $0.45 \% \mathrm{TiO}_{2}-0.45 \% \mathrm{CNT}$ & 189 & -196 \\
\hline $0.2 \% \mathrm{TiO}_{2}-0.7 \% \mathrm{CNT}$ & 584 & -216 \\
\hline $0.9 \% \mathrm{CNT}$ & 117 & -119 \\
\hline $18 \mathrm{M} \Omega \mathrm{H}_{2} \mathrm{O}$ & 52 & -101 \\
\hline
\end{tabular}




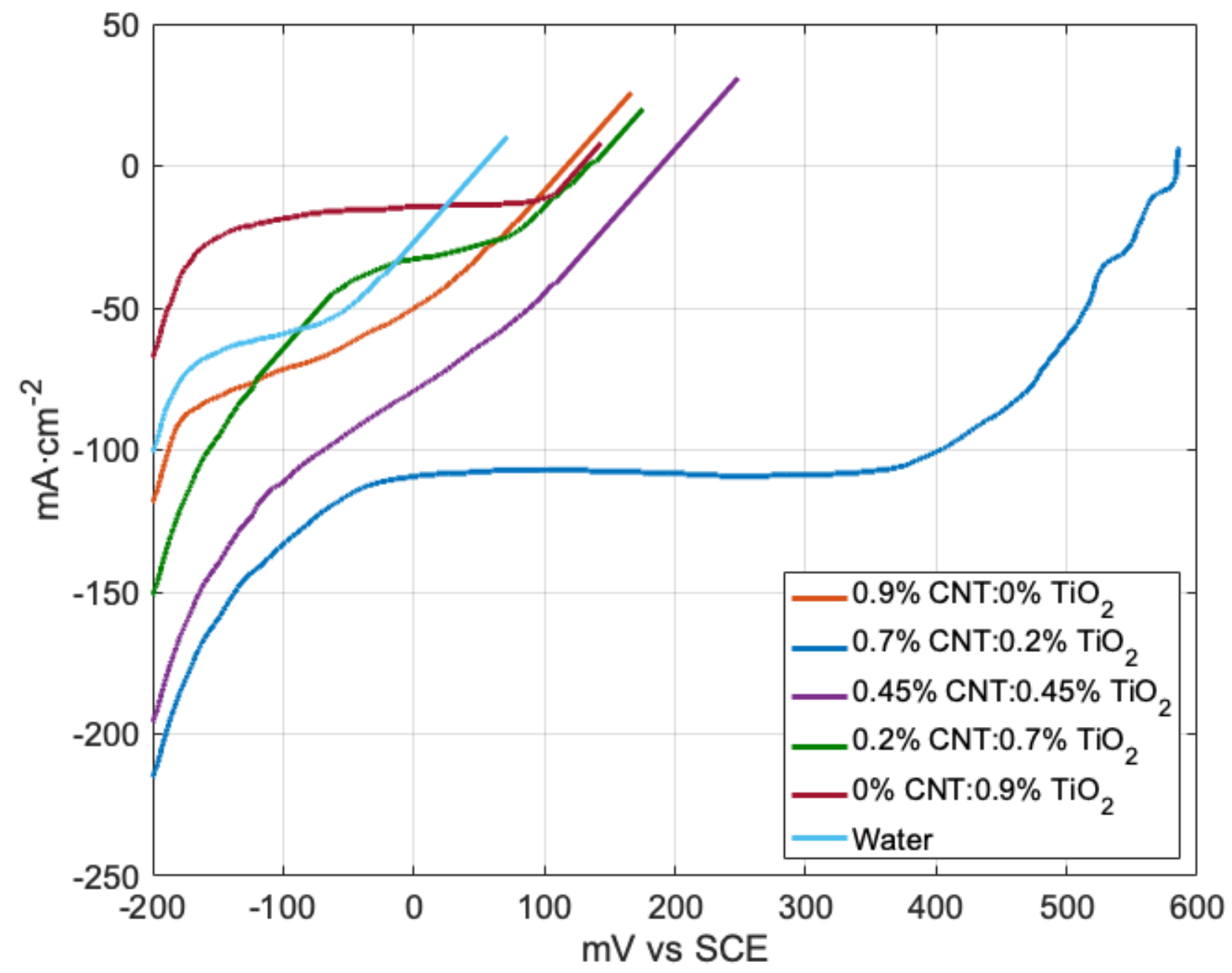

Figure 6. Linear sweep voltammograms of the different coating compositions in sterile AGYEB containing $30 \mathrm{U} / \mathrm{mL}$ of pure laccase.

Comparing the current densities of laccase electrodes at potentials less than $+400 \mathrm{mV}$ vs. SCE quantifies their performance while excluding oxygen transport limitations [23]. The $0.7 \% \mathrm{TiO}_{2}-0.2 \% \mathrm{CNT}$ coating had a current density of $-100 \mathrm{~mA} / \mathrm{cm}^{2}$ at $+400 \mathrm{mV}$ vs. SCE, 3\% higher than a similar setup utilizing pure laccase adsorbed onto a buckypaper cathode [23]. For all other coating compositions, low laccase loading or poor electrical contact between the enzyme and the electrode lowered the open circuit potential to near $+100 \mathrm{mV}$ vs. SCE, so the current densities at $-200 \mathrm{mV}$ vs. SCE were reported in Table 1. Table 1 and Figure 6 show a trend whereby increasing the weight percent of CNT in the $\mathrm{CNT}-\mathrm{TiO}_{2}-\mathrm{Nafion}$ coating raised the OCP except for when the coating was composed entirely of $\mathrm{CNT}, \mathrm{TiO}_{2}$ or Nafion.

At lower carbon nanotube loading, the number of direct electron transfer sites accessible to laccases is insufficient to promote efficient oxygen reduction, resulting in a lower open circuit potential and low current density (Figure 6). However, at higher CNT loading, the nanotubes form aggregates, significantly diminishing the effective surface area of the coating [48-50]. This phenomenon is observable in the linear sweep voltammograms, wherein a coating composed entirely of CNT has nearly the same open circuit potential as one composed entirely of $\mathrm{TiO}_{2}$. In these cases, the nanostructures appear to have increased the porosity of the coating, but have not created a significant number of sites where laccase can directly transfer electrons to the cathode. Equal amounts of CNT and $\mathrm{TiO}_{2}$ increased the OCP to $250 \mathrm{mV}$, but the best performance was from $0.7 \% \mathrm{CNT}$ and $0.2 \% \mathrm{TiO}_{2}$.

A scanning electron micrograph of the optimized coating taken 4 days after inoculation is depicted in Figure 7. The large $\sim 10 \mu \mathrm{m}$ structures are the fibrous, highly porous $\mathrm{TiO}_{2}-$ CNT-Nafion coating [51], and the smaller $\sim 5 \mu \mathrm{m}$ structures are the fungal hyphae [52]. 
The larger coating structures spatially distribute the fungal hyphae, while the nanoscale components promote enzyme exchange between the fungus and the electrode, and facilitate high enzyme loading with electrical contact to the electrode.

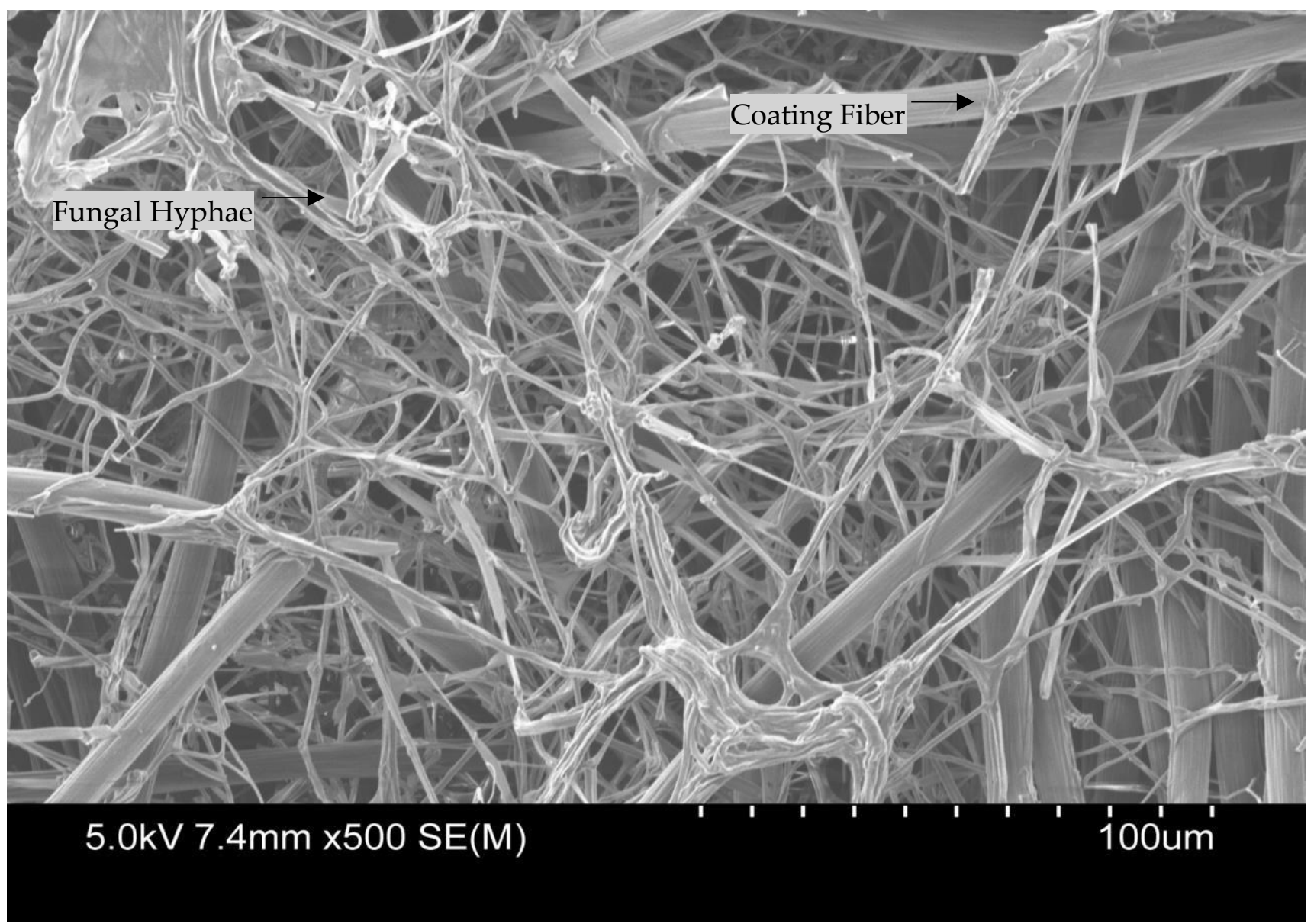

Figure 7. Scanning electron micrograph of the optimized coating with T. versicolor growing on top of the coating.

\subsection{Comparison of Electrochemical Properties with and without Enzyme Regeneration}

The current density of pure laccase in sterile electrolyte without fungus was $20 \%$ higher than that of the crude laccase from the T. versicolor culture without fungus (Figure 8a). This discrepancy is supported by the proteomics data (Figure 5), which confirm the presence of electrochemically inert enzymes in the crude filtrate. Inert enzymes such as glucose oxidase and manganese peroxidase can occupy direct electron transfer sites that are otherwise used by laccase to produce current [43]. Incorporating the fungus at the cathode lowered the open circuit potential of the pure laccase treatment by $24 \mathrm{mV}$ (Figure $8 \mathrm{~b}$ ). The presence of the fungus raised the current density and open circuit potential of the crude laccase treatment to $-52 \mathrm{~mA} / \mathrm{cm}^{2}$ and $524 \mathrm{mV}$, respectively. The higher performance of crude filtrate over pure laccase is in agreement with the findings of Sane et al. (2013) [23], and could be associated with the preservation of posttranslational protein modifications, such as glycosylation [37], or the secretion of uncharacterized mediators [53], which may be lost in the protein purification process [54]. 

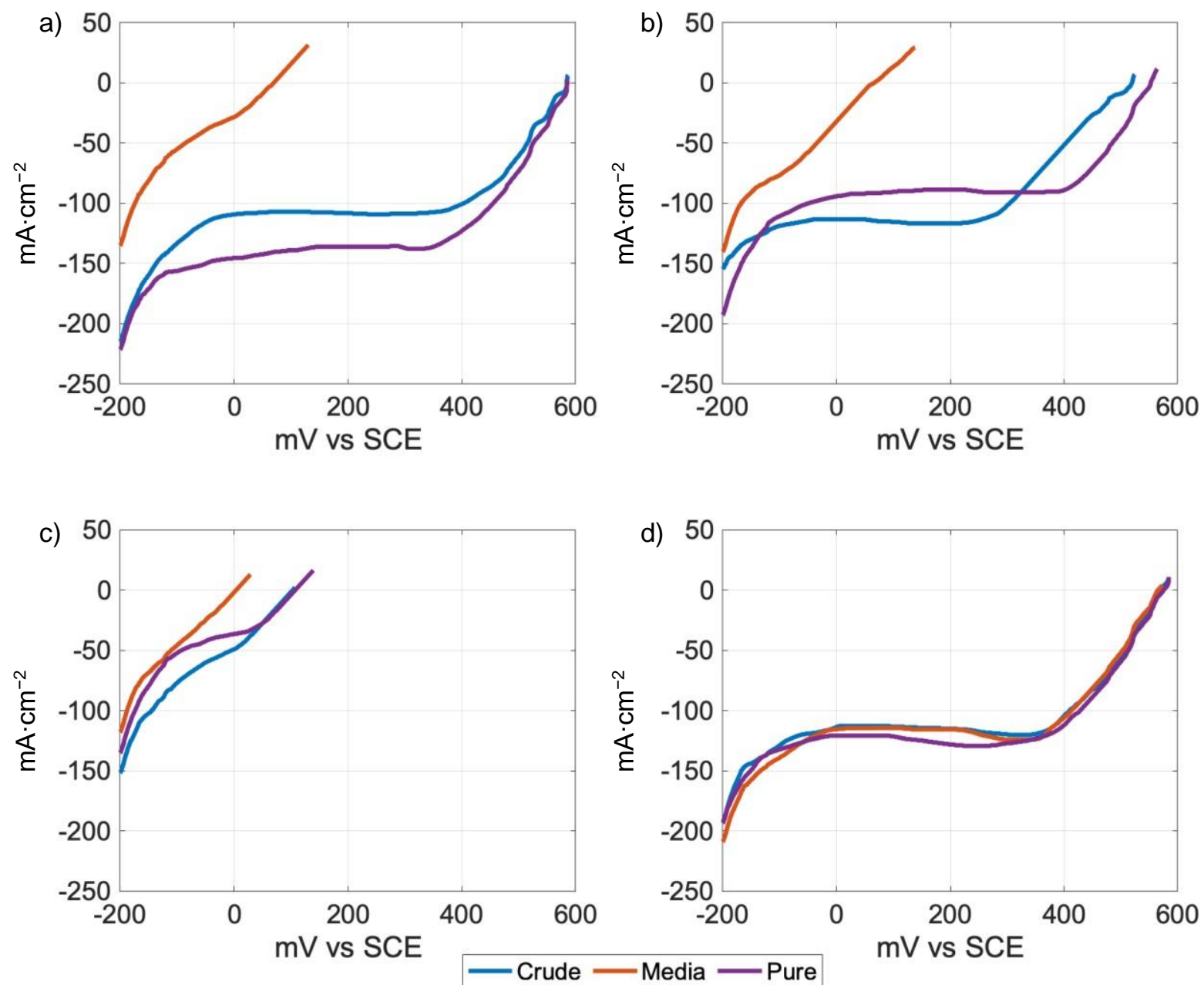

Figure 8. Linear sweep voltammograms of (a) the optimized coating in three different electrolytes without $T$. versicolor on the cathode, (b) the optimized coating with T. versicolor grown on the cathode for two days, (c) the optimized coating without $T$. versicolor on the cathode after two days of operation, and (d) the optimized coating with $T$. versicolor growing on the cathode after two days of operation.

Forty-eight hours after introducing electrolyte to the fuel cells, linear sweep voltammetry was performed again. In cultures without T. versicolor (Figure 8c), the open circuit potential and current density were significantly diminished. However, in cultures with T. versicolor growing on the cathode, current density and open circuit potential were aligned (Figure 8d). Interestingly, the performance of the media control, containing no laccase at initiation, was "rescued" by the presence of the fungus. The higher bioelectrocatalytic activity of the electrodes indicates that the active laccases produced by the fungus are successfully exchanged with the inactive laccases previously adsorbed onto the cathode.

\section{Discussion}

Biological fuel cells continue to gain recognition as a solution to global energy challenges due to their multifunctionality [2]. However, neither enzymatic nor microbial fuel cells have achieved commercial viability due to their short lifetimes and low current densities $[31,32,55,56]$. The hybrid microbial-enzymatic fuel cell combines the higher current density of enzymatic fuel cells with the longevity of microbial fuel cells. Additionally, the hybrid microbial-enzymatic fuel cell demonstrates the feasibility of a self-regenerating fuel cell cathode, in which an enzyme-producing microbe is incorporated into the electrode by continuously recycling inactive laccases to active laccases. 
In comparison to the recently presented microbial cathode, in which T. versicolor was grown in the catholyte, our approach is advantageous, as it incorporates the fungus at the cathode, precluding the need for mediators, which have a limited lifetime [22,57]. This proof-in-concept work demonstrated the feasibility of using unpurified fungal culture broth as an electrolyte in a laccase-based cathode. Directly incorporating the laccase-producing fungus at the cathode overcomes the limitations imposed by the short lifetime of laccases, while eliminating the need for the frequent replenishment of the electrolyte. However, the current density at $+400 \mathrm{mV}$ vs. SCE was $-112 \mathrm{~mA} / \mathrm{cm}^{2}, 13 \%$ lower than a laccase fuel cell without fungus, which utilized crude laccase adsorbed onto a buckypaper cathode, as operated by Sane et al. [23]. The hybrid microbial-enzymatic cathode addresses the issue of enzyme inactivation by using the natural ability of fungi to exchange inactive laccases with active laccases, at the cost of slightly lower current density.

The production of edible and medicinal biomass was used as the metric to analyze the secondary benefits of this system. T. versicolor has shown promise in boosting the immune response in cancer patients, and increasing lymphocyte counts, natural killer cell functional activity, CD8 + T cell counts, and CD19+ B cell counts [58]. These benefits have come from taking capsules of freeze-dried fungal biomass produced for consumption. Pleurotus ostreatus is a gourmet mushroom with a highly sought-after taste and high mineral content $[59,60]$. The increasing adoption of plant-based proteins provides a growing market for P. ostreatus biomass [61,62], which is produced in the hybrid microbial-enzymatic cathode. The harvesting of fungal biomass for edible and medicinal purposes represents a new area of high-profit secondary benefits $[63,64]$ that should be explored as an avenue to amend the functionality of microbial fuel cells. Temperature and $\mathrm{pH}$ impact laccase activity [65-68] and fungal biomass production [35-37]. Once a fungal byproduct is decided upon, variable $\mathrm{pH}$ and temperature studies should be carried out to optimize the production of electricity and biomass for the intended application. Fungi are also adept at heavy metal sequestration and waste remediation, which presents opportunities to customize and combine secondary benefits based on application $[69,70]$.

The various ecological roles played by filamentous fungi in nature allow the hybrid microbial-enzymatic fuel cell to be tuned to provide a variety of secondary and tertiary benefits during operation. Future research will explore the use of additional fungi, and the genetic and cultural conditions that can increase the laccase composition of the secretome in the fungi of interest, as well as reducing the number of detrimental (peroxidase) and metabolic (glucose oxidase and glycosidase) enzymes in the extracellular environment.

\section{Materials and Methods}

Unless otherwise stated, all chemicals were of reagent grade and purchased from Sigma Aldrich (St. Louis, MO, USA). Bacto yeast extract was obtained from Fisher Scientific (San Diego, CA, USA); T. versicolor laccase standard (13.6 U/mg) was purchased from MyBioSource (Cerritos, CA, USA). P. ostreatus var. pearl, P. ostreatus var. blue, and T. versicolor were purchased from Fungi Perfecti (Olympia, WA, USA); P. ostreatus var. N001 was purchased from American Type Culture Collection (http:/ /www.atcc.org//ps/32783.ashx); F. oxysporum f.s. lycopersici was obtained from Dr. Hans VanEtten (The University of Arizona, Tucson, AZ, USA). The $500 \mathrm{~mL}$ media bottles and $50 \mathrm{~mL}$ miniature bioreactors were purchased from Dow Corning (Midland, MI, USA); single-wall carbon nanotubes (95 wt \%; OD: 10-20 nm; ID: 5-10 nm; L: 10-30 $\mu \mathrm{m}$ ) were provided by Dr. Mike Foley (CTI Materials, Grafton, VT, USA). Spectroscopic carbon rods were purchased from Ted Pella Inc (Redding, CA, USA). PTFE heat shrink tubing was purchased from McMaster Carr Inc. (Elmhurst, IL, USA). Difco yeast extract was purchased from Fisher Scientific (Waltham, MA, USA).

All fungi were maintained on $100 \mathrm{~mm} \times 15 \mathrm{~mm}$ petri dishes containing glucose yeast extract agar (GYEA) composed of $1 \%$ glucose, $1 \%$ yeast extract, and $1.5 \%$ agar. In total, $10 \mathrm{~mL}$ of acidified glucose yeast extract broth at $\mathrm{pH} 4.5$ (1\% glucose, $1 \%$ yeast extract, $1 \%$ succinic acid) was dispensed onto a 7-day-old culture to create pre-inoculum. The mycelium was dislodged from the plate using a $10 \mathrm{~mL}$ wide-bore pipette and the resulting 
slurry was added to $190 \mathrm{~mL}$ of AGYEB in a sterile $500 \mathrm{~mL}$ reagent bottle. The reagent bottles were kept shaking at $250 \mathrm{rpm}$ and $27^{\circ} \mathrm{C}$ for 7 days. The resulting inoculum was used at $10 \%$ volume-to-volume ratio to inoculate all experimental cultures. Experimental culture conditions were as follows: $500 \mathrm{~mL}$ media bottles and $50 \mathrm{~mL}$ bioreactors were filled with $200 \mathrm{~mL}$ and $20 \mathrm{~mL}$ AGYEB, respectively. Cultures were either kept shaking at $250 \mathrm{rpm}$ or $0 \mathrm{rpm}$. All fungi were grown at $27^{\circ} \mathrm{C}$ for the predetermined time course. After $72 \mathrm{~h}$ of growth an inducer was added aseptically to promote laccase secretion. After the appropriate time course, cultures were filtered through pre-weighed cheesecloth, then cell-free filtrate was collected using $0.45 \mu \mathrm{m}$ low-protein binding cellulose acetate filters. After straining, the fungal biomass and the cheesecloth were placed into beakers, frozen at $-80{ }^{\circ} \mathrm{C}$, and lyophilized under a 200 militorr vacuum at $-60{ }^{\circ} \mathrm{C}$. Dry biomass was determined by weighing the biomass-cheesecloth combination and subtracting the weight of the cheesecloth.

Laccase activity in the cell-free filtrate was determined spectrophotometrically using a Bio Tek Synergy II microplate reader with microinjector [71]. Total protein was quantified using the Bradford assay [72]. Briefly, one-part cell-free filtrate was used to one-part Bradford reagent, and absorbance was monitored at $595 \mathrm{~nm}$ after $10 \mathrm{~min}$. Then, $100 \mu \mathrm{L}$ of sample, standard, or blank was pipetted into the corresponding well, and $100 \mu \mathrm{L}$ of $2 \mathrm{mM}$ ABTS (2,20-azino-bis(3-ethylbenzthiazoline-6-sulphonic acid)) was injected into each well of the plate and absorbance was read at $410 \mathrm{~nm}$ continuously after injection. The reaction was allowed to proceed for $10 \mathrm{~min}$ at $27^{\circ} \mathrm{C}$ under the medium shaking condition. Data reduction was performed according to the standard fluorometric protein quantification parameters in the Gen5 software (Version 2.09, BioTek, Winooski, VT, USA, 2012) provided with the reader. ANOVA and a multiple comparison mean tests were performed in MATLAB 2020b (Mathworks, Natick, MA, USA) according using Sídák's multiple comparisons test for one way ANOVA (Figures 2 and 4) and two-stage linear step-up procedure of Benjamini, Krieger and Yekutieli for two-way ANOVA (Figure 3) [73].

Cell-free filtrates were also prepared for proteomics, then passed through $0.22 \mu \mathrm{m}$ low-protein binding syringe filters (Fisher Scientific, San Diego, CA, USA). The resulting solution was ultrafiltered using an Amicon stirred cell concentrator (MerckMillipore, Temecula, CA, USA) [74]. After ultrafiltration, the concentrated protein solution was dialyzed against 50mM ammonium bicarbonate $\mathrm{pH} 7.5$. The dialysates were frozen until they were sent to the University of Arizona's proteomics core facility. Tandem mass spec analysis was performed using a LTQ Orbitrap Velos mass spectrometer (Fisher Scientific, Waltham, MA, USA) equipped with a nano electrospray ion source; the instrument was operated in data-dependent acquisition mode. Raw data were processed using Scaffold Proteome Software (Version 3.6.5, Proteome Software Inc., Portland, OR, USA, 2012).

The tops of the spectroscopic carbon rods were passivated using PTFE heat shrink tubing (McMasterCarr, Cleveland, $\mathrm{OH}$, USA). The surface area was normalized to $10 \mathrm{~cm}^{2}$ after modification with PTFE. Dip coating solutions of $0.9 \mathrm{wt}$. \% were created with varying amounts of titanium dioxide and CNT and cured at $120{ }^{\circ} \mathrm{C}$ for three minutes. Single-walled carbon nanotubes (SWCNTs) have been used in the past to impart electronic conductivity to fuel cells, sensors, and bio-electronics [75,76]. The dimensions of SWCNTs facilitate the direct physical connections between the electrode and enzyme while the inherent conductivity of SWCNTs establishes an electrical connection [45]. Though other carbon nanostructes are more sustainable in terms of cost and environmental toxicity [77-79], SWCNTs were selected to facilitate direct electron transfer between the electrode and enzymatic catalyst by decreasing the electron tunneling distance [12].

Titanium dioxide nanoparticles were synthesized by adding tetramethylammonium hydroxide to titanium isopropoxide in a 1:1 ratio, then 3 parts $18 \mathrm{M} \Omega$ deionionized water was added, and the mixture was stirred at $95{ }^{\circ} \mathrm{C}$ for $2 \mathrm{~h}$, then the solution was peptized at $70{ }^{\circ} \mathrm{C}$ for $48 \mathrm{~h}$ [80]. The resulting solution was passed through a $0.2 \mu \mathrm{m}$ filter and $1 \mathrm{~mL}$ aliquots were placed in a roto evaporator to determine the final concentration of nanoparticles. The stock solution was diluted to $20 \mathrm{wt} \%$ using $18 \mathrm{M} \Omega$ deionionized water, 
and the resulting working solution was stored at $2{ }^{\circ} \mathrm{C}$. Electrodes were dipped into the same solution three times; a constant pull rate of $2 \mathrm{~mm} / \mathrm{s}$ was used for all coatings. The electrodes were then dip coated in $0.1 \%$ Nafion under sterile conditions at the same pull rate. For microbe-containing coatings, functionalized electrodes were placed on $1 \mathrm{~mm} \times 3 \mathrm{~mm}$ round carbon supports in the $20 \mathrm{~mL}$ bioreactors and fungi were allowed to colonize for two days before electrochemical measurements were taken.

All electrochemical measurements were carried out on a Biologic VSP potentiostat (Biologic, Seyssinet-Pariset, Grenoble, France) with a saturated calomel reference electrode (Gamry Instruments, Warminster, PA, USA) and a $10 \mathrm{~cm} \times 0.5 \mathrm{~cm}$ carbon counter electrode (Sigma Aldrich, St. Louis, MO, USA). Functionalized $0.32 \mathrm{~cm} \times 10 \mathrm{~cm}$ spectroscopic carbon rods were used as working electrodes. The catholyte was stirred for $10 \mathrm{~min}$ under air before open circuit potential was determined and linear sweep voltammetry began. Catholytes were either sterile AGYEB (media), crude T. versiolor filtrate (crude), or sterile AGYEB spiked with purified T. versicolor laccase (pure). Sweeps were started at $-200 \mathrm{mV}$ vs. SCE and run to the open circuit potential of the electrode at a scan rate of $50 \mathrm{mV} / \mathrm{s}$.

\section{Conclusions}

Laccase-secreting fungi were grown directly on the cathode of a biological fuel cell constructed with a multifunctional cathode coating of titanium dioxide nanoparticles and carbon nanotubes. Culturing studies show that smaller reaction vessels increased the amount of laccase produced by most of the tested species. In T. versicolor, copper sulfate increased the laccase proportion of the secretome by $21 \%$ compared to the negative control. Electrochemical experiments demonstrated improvements in enzyme loading and cell longevity when the fungus was grown on the cathode. The ten-fold increase in open circuit potential demonstrated the ability of the optimized cathode coating to increase enzyme loading compared to the other tested coating compositions. The initial current density was higher without the fungus, but the presence of the fungus increased both the current density and the open circuit potential of the laccase cathodes at $48 \mathrm{~h}$ of continuous operation. The hybrid microbial-enzymatic fuel cell combines the higher current density of enzymatic fuel cells with the longevity of microbial fuel cells, and demonstrates the feasibility of a self-regenerating fuel cell cathode in which inactive laccases are continuously exchanged with active laccases.

Author Contributions: Conceptualization, J.P.E., B.M.P., and D.F.G.; methodology, B.M.P. and D.F.G.; validation, J.P.E., B.M.P., and D.F.G.; formal analysis, J.P.E.; investigation, J.P.E.; resources, B.M.P., and D.F.G.; data curation, J.P.E.; writing—original draft preparation, J.P.E.; writing—review and editing, B.M.P. and D.F.G.; visualization, J.P.E.; supervision, B.M.P., and D.F.G.; project administration, B.M.P., and D.F.G.; funding acquisition, B.M.P., and D.F.G. All authors have read and agreed to the published version of the manuscript.

Funding: This research was funded by The University of Arizona Green Fund grant number GF 15.13.

Data Availability Statement: The data presented in this study are available upon request from the corresponding author.

Acknowledgments: The authors thank the University of Arizona Proteomics and Imaging Cores for their assistance with the collection of proteomic and scanning electron micrographs, respectively.

Conflicts of Interest: The authors declare no conflict of interest. The funders had no role in the design of the study; in the collection, analyses, or interpretation of data; in the writing of the manuscript, or in the decision to publish the results.

\section{References}

1. Spiegel, C. Designing and Building Fuel Cells; Mcgraw-Hill: New York, NY, USA, 2007; Volume 87.

2. Vielstich, W.; Lamm, A.; Gasteiger, H.A. Handbook of Fuel Cells: Fundamentals Technology and Applications; Wiley: New York, NY, USA, 2003; Volume 2.

3. Minteer, S.D.; Liaw, B.Y.; Cooney, M.J. Enzyme-based biofuel cells. Curr. Opin. Biotechnol. 2007, 18, 228-234. [CrossRef]

4. Moehlenbrock, M.J.; Minteer, S.D. Extended lifetime biofuel cells. Chem. Soc. Rev. 2008, 37, 1188-1196. [CrossRef] 
5. $\quad$ Bhatt, M.D.; Lee, J.Y. Advancement of Platinum (Pt)-Free (Non-Pt Precious Metals) and/or Metal-Free (Non-Precious Metals) Electrocatalysts in Energy Applications: A Review and Perspectives. Energy Fuels 2020, 34, 6634-6695. [CrossRef]

6. Kim, J.; Jia, H.; Wang, P. Challenges in biocatalysis for enzyme-based biofuel cells. Biotechnol. Adv. 2006, 24, 296-308. [CrossRef] [PubMed]

7. Togo, M.; Oike, M.; Kaji, H.; Abe, T.; Nishizawa, M. Stepwise electric power generation for prolonging lifetime of miniaturized biofuel cell. In Proceedings of the 214th Meeting of the Electrochemical Society, Sendai, Japan, 17-19 November 2008 ; Volume 1422.

8. Yeager, E. Electrocatalysts for O2 reduction. Electrochim. Acta 1984, 29, 1527-1537. [CrossRef]

9. Kakarla, R.; Min, B. Evaluation of microbial fuel cell operation using algae as an oxygen supplier: Carbon paper cathode vs. carbon brush cathode. Bioprocess Biosyst. Eng. 2014, 37, 2453-2461. [CrossRef] [PubMed]

10. Larminie, J.; Dicks, A.; McDonald, M.S. Fuel Cell Systems Explained; J. Wiley: Chichester, UK, 2003; Volume 2.

11. Stauffer, D.B.; Hirschenhofer, J.H.; Klett, M.G.; Engleman, R.R. Fuel Cell Handbook; (No. DOE/FETC-99/1076); Federal Energy Technology Center (FETC): Morgantown, WV, USA; Pittsburgh, PA, USA, 1998.

12. Minteer, S.D.; Atanassov, P.; Luckarift, H.R.; Johnson, G.R. New materials for biological fuel cells. Mater. Today 2012, 1, 166-173. [CrossRef]

13. Horozova, E.; Dimcheva, N. Kinetic study of catalase adsorption on disperse carbonaceous matrices. Cent. Eur. J. Chem. 2004, 2, 627-637. [CrossRef]

14. Ye, J.S.; Wen, Y.; De Zhang, W.; Cui, H.F.; Xu, G.Q.; Sheu, F.S. Electrochemical biosensing platforms using phthalocyaninefunctionalized carbon nanotube electrode. Electroanal. Int. J. Devoted Fundam. Pract. Asp. Electroanal. 2005, 17, 89-96. [CrossRef]

15. Ramasamy, R.P.; Luckarift, H.R.; Ivnitski, D.M.; Atanassov, P.B.; Johnson, G.R. High electrocatalytic activity of tethered multicopper oxidase-carbon nanotube conjugates. Chem. Commun. 2010, 46, 6045-6047. [CrossRef] [PubMed]

16. Coll, P.M.; Perez, P.; Villar, E.; Shnyrov, V.L. Domain structure of laccase I from the lignin-degrading basidiomycete PM1 revealed by differential scanning calorimetry. Biochem. Mol. Biol. Int. 1994, 34, 1091-1098.

17. Parimi, N.S.; Umasankar, Y.; Atanassov, P.; Ramasamy, R.P. Kinetic and mechanistic parameters of laccase catalyzed direct electrochemical oxygen reduction reaction. ACS Catal. 2012, 2, 38-44. [CrossRef]

18. Kataoka, K.; Sugiyama, R.; Hirota, S.; Inoue, M.; Urata, K.; Minagawa, Y.; Sakurai, T. Four-electron reduction of dioxygen by a multicopper oxidase, CueO, and roles of Asp112 and Glu506 located adjacent to the trinuclear copper center. J. Biol. Chem. 2009, 284, 14405-14413. [CrossRef]

19. Palmore, G.T.R.; Kim, H.H. Electro-enzymatic reduction of dioxygen to water in the cathode compartment of a biofuel cell. J. Electroanal. Chem. 1999, 464, 110-117. [CrossRef]

20. Zhang, Y.; Lv, Z.; Zhou, J.; Xin, F.; Ma, J.; Wu, H.; Dong, W. Application of eukaryotic and prokaryotic laccases in biosensor and biofuel cells: Recent advances and electrochemical aspects. Appl. Microbiol. Biotechnol. 2018, 102, 10409-10423. [CrossRef] [PubMed]

21. Rubenwolf, S.; Strohmeier, O.; Kloke, A.; Kerzenmacher, S.; Zengerle, R.; von Stetten, F. Carbon electrodes for direct electron transfer type laccase cathodes investigated by current density-cathode potential behavior. Biosens. Bioelectron. 2010, 26, 841-845. [CrossRef] [PubMed]

22. Rubenwolf, S.; Kestel, J.; Kerzenmacher, S.; Zengerle, R.; von Stetten, F. Enhancing the lifetime of laccase-based biofuel cell cathodes by sequential renewal of enzyme. In Proceedings of the 60th Annual Meeting of the International Society of Electrochemistry, Beijing, China, 16-21 August 2009.

23. Sané, S.; Jolivalt, C.; Mittler, G.; Nielsen, P.J.; Rubenwolf, S.; Zengerle, R.; Kerzenmacher, S. Overcoming bottlenecks of enzymatic biofuel cell cathodes: Crude fungal culture supernatant can help to extend lifetime and reduce cost. ChemSusChem 2013, 6, 1209-1215. [CrossRef]

24. Stanzione, I.; Pezzella, C.; Giardina, P.; Sannia, G.; Piscitelli, A. Beyond natural laccases: Extension of their potential applications by protein engineering. Appl. Microbiol. Biotechnol. 2020, 104, 915-924. [CrossRef]

25. Mate, D.M.; Alcalde, M. Laccase engineering: From rational design to directed evolution. Biotechnol. Adv. 2015, 33, 25-40. [CrossRef]

26. Maté, D.; García-Burgos, C.; García-Ruiz, E.; Ballesteros, A.O.; Camarero, S.; Alcalde, M. Laboratory evolution of high-redox potential laccases. Chem. Biol. 2010, 17, 1030-1041. [CrossRef] [PubMed]

27. Mateljak, I.; Monza, E.; Lucas, M.F.; Guallar, V.; Aleksejeva, O.; Ludwig, R.; Leech, D.; Shleev, S.; Alcalde, M. Increasing redox potential, redox mediator activity, and stability in a fungal laccase by computer-guided mutagenesis and directed evolution. ACS Catal. 2019, 9, 4561-4572. [CrossRef]

28. Mateljak, I.; Rice, A.; Yang, K.; Tron, T.; Alcalde, M. The generation of thermostable fungal laccase chimeras by SCHEMA-RASPP structure-guided recombination in vivo. ACS Synth. Biol. 2019, 8, 833-843. [CrossRef]

29. Furukawa, T.; Sawaguchi, C.; Watanabe, A.; Takahashi, M.; Nigorikawa, M.; Furukawa, K.; Iimura, Y.; Kajita, S.; Oguchi, T.; Ito, Y.; et al. Application of fungal laccase fused with cellulose-binding domain to develop low- lignin rice plants. J. Biosci. Bioeng. 2013, 116, 616-619. [CrossRef]

30. Galli, C.; Gentili, P.; Jolivalt, C.; Madzak, C.; Vadalà, R. How is the reactivity of laccase affected by single-point mutations? Engineering laccase for improved activity towards sterically demanding substrates. Appl. Microbiol. Biotechnol. 2011, 91, 123-131. [CrossRef] 
31. Zhu, Z.; Momeu, C.; Zakhartsev, M.; Schwaneberg, U. Making glucose oxidase fit for biofuel cell applications by directed protein evolution. Biosens. Bioelectron. 2006, 21, 2046-2051. [CrossRef]

32. Güven, G.; Prodanovic, R.; Schwaneberg, U. Protein engineering-An option for enzymatic biofuel cell design. Electroanal. Int. J. Devoted Fundam. Pract. Asp. Electroanal. 2010, 22, 765-775. [CrossRef]

33. Yamaguchi, M.; Tahara, Y.; Nakano, A.; Taniyama, T. Secretory and continuous expression of Aspergillus niger glucose oxidase gene in Pichia pastoris. Protein Expr. Purif. 2007, 55, 273-278. [CrossRef] [PubMed]

34. Christenson, A.; Dimcheva, N.; Ferapontova, E.E.; Gorton, L.; Ruzgas, T.; Stoica, L.; Shleev, S.; Yaropolov, A.I.; Haltrich, D.; Thorneley, R.N.; et al. Direct electron transfer between ligninolytic redox enzymes and electrodes. Electroanal. Int. J. Devoted Fundam. Pract. Asp. Electroanal. 2004, 16, 1074-1092. [CrossRef]

35. Canero, D.C.; Roncero, M.I.G. Functional analyses of laccase genes from Fusarium oxysporum. Phytopathology 2008, 98, 509-518. [CrossRef] [PubMed]

36. Thangadurai, D.; Sangeetha, J.; David, M. Fundamentals of Molecular Mycology; CRC Press: Boca Raton, FL, USA, 2016.

37. Patel, H.; Gupte, S.; Gahlout, M.; Gupte, A. Purification and characterization of an extracellular laccase from solid-state culture of Pleurotus ostreatus HP-1. 3 Biotech 2014, 4, 77-84. [CrossRef] [PubMed]

38. Baldrian, P. Fungal laccases-occurrence and properties. FEMS Microbiol. Rev. 2006, 30, 215-242. [CrossRef]

39. Stamets, P.E. Notes on nutritional properties of culinary-medicinal mushrooms. Int. J. Med. Mushrooms 2005, 7, 103-110. [CrossRef]

40. Nagygyörgy, E.; Kovács, B.; Leiter, É.; Miskei, M.; Pócsi, I.; Hornok, L.; Ádám, A. Toxicity of abiotic stressors to Fusarium species: Differences in hydrogen peroxide and fungicide tolerance. Acta Microbiol. Immunol. Hung. 2014, 61, 189-208. [CrossRef] [PubMed]

41. Finnegan, M.; Linley, E.; Denyer, S.P.; McDonnell, G.; Simons, C.; Maillard, J.Y. Mode of action of hydrogen peroxide and other oxidizing agents: Differences between liquid and gas forms. J. Antimicrob. Chemother. 2010, 65, 2108-2115. [CrossRef] [PubMed]

42. Müntz, K. Protein dynamics and proteolysis in plant vacuoles. J. Exp. Bot. 2007, 58, 2391-2407. [CrossRef] [PubMed]

43. Rubenwolf, S.; Sané, S.; Hussein, L.; Kestel, J.; von Stetten, F.; Urban, G.; Kerzenmacher, S. Prolongation of electrode lifetime in biofuel cells by periodic enzyme renewal. Appl. Microbiol. Biotechnol. 2012, 96, 841-849. [CrossRef] [PubMed]

44. Makhdoomi, H.; Moghadam, H.M.; Zabihi, O. Effect of different conditions on the size and quality of titanium dioxide nanoparticles synthesized by a reflux process. Res. Chem. Intermed. 2015, 41, 1777-1788. [CrossRef]

45. Kim, J.H.; Hwang, J.Y.; Hwang, H.R.; Kim, H.S.; Lee, J.H.; Seo, J.W.; Shin, U.S.; Lee, S.-H. Simple and cost-effective method of highly conductive and elastic carbon nanotube/polydimethylsiloxane composite for wearable electronics. Sci. Rep. 2018, 8, 1-11. [CrossRef] [PubMed]

46. Tarasevich, M.R.; Bogdanovskaya, V.A.; Kuznetsova, L.N. Bioelectrocatalytic reduction of oxygen in the presence of laccase adsorbed on carbon electrodes. Russ. J. Electrochem. 2001, 37, 833-837. [CrossRef]

47. Choi, H.N.; Han, J.H.; Park, J.A.; Lee, J.M.; Lee, W.Y. Amperometric glucose biosensor based on glucose oxidase encapsulated in carbon nanotube-titania-Nafion composite film on platinized glassy carbon electrode. Electroanal. Int. J. Devoted Fundam. Pract. Asp. Electroanal. 2007, 19, 1757-1763. [CrossRef]

48. Koh, B.; Cheng, W. Mechanisms of carbon nanotube aggregation and the reversion of carbon nanotube aggregates in aqueous medium. Langmuir 2014, 30, 10899-10909. [CrossRef]

49. Yang, Q.S.; He, X.Q.; Liu, X.; Leng, F.F.; Mai, Y.W. The effective properties and local aggregation effect of CNT/SMP composites. Compos. Part B Eng. 2012, 43, 33-38. [CrossRef]

50. Mathieu, B.; Anthony, C.; Arnaud, A.; Lionel, F. CNT aggregation mechanisms probed by electrical and dielectric measurements. J. Mater. Chem. C 2015, 3, 5769-5774. [CrossRef]

51. Mynttinen, E.; Wester, N.; Lilius, T.; Kalso, E.; Mikladal, B.; Varjos, I.; Sainio, S.; Jiang, H.; Kauppinen, E.I.; Koskinen, J.; et al. Electrochemical detection of oxycodone and its main metabolites with Nafion-coated single-walled carbon nanotube electrodes. Anal. Chem. 2020, 92, 8218-8227. [CrossRef] [PubMed]

52. Lehmann, A.; Zheng, W.; Soutschek, K.; Roy, J.; Yurkov, A.M.; Rillig, M.C. Tradeoffs in hyphal traits determine mycelium architecture in saprobic fungi. Sci. Rep. 2019, 9, 1-9.

53. Rittstieg, K.; Suurnäkki, A.; Suortti, T.; Kruus, K.; Guebitz, G.M.; Buchert, J. Polymerization of Guaiacol and a Phenolic

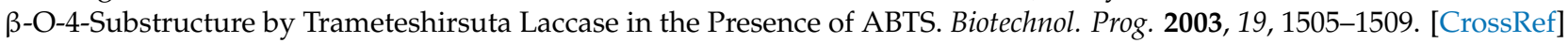

54. McFedries, A.; Schwaid, A.; Saghatelian, A. Methods for the elucidation of protein-small molecule interactions. Chem. Biol. 2013, 20, 667-673. [CrossRef]

55. Koroglu, E.O.; Yoruklu, H.C.; Demir, A.; Ozkaya, B. Scale-up and commercialization issues of the MFCs: Challenges and implications. In Microbial Electrochemical Technology; Elsevier: Amsterdam, The Netherlands, 2019; pp. 565-583.

56. Krieg, T.; Wood, J.A.; Mangold, K.M.; Holtmann, D. Mass transport limitations in microbial fuel cells: Impact of flow configurations. Biochem. Eng. J. 2018, 138, 172-178. [CrossRef]

57. Binyamin, G.; Chen, T.; Heller, A. Sources of instability of 'wired'enzyme anodes in serum: Urate and transition metal ions. J. Electroanal. Chem. 2001, 500, 604-611. [CrossRef]

58. Guggenheim, A.G.; Wright, K.M.; Zwickey, H.L. Immune modulation from five major mushrooms: Application to integrative oncology. Integr. Med. A Clin. J. 2014, 13, 32. 
59. Royse, D.J. A global perspective on the high five: Agaricus, Pleurotus, Lentinula, Auricularia \& Flammulina. In Proceedings of the 8th International Conference on Mushroom Biology and Mushroom Products (ICMBMP8), New Delhi, India, 19-22 November 2014; Volume 1, pp. 1-6.

60. Moore, D.; Chiu, S.W. Fungal Products as Food. In Bio-Exploitation of Filamentous Fungi; Fungal Diversity Press: Hong Kong, China, 2001.

61. Cardwell, G.; Bornman, J.F.; James, A.P.; Black, L.J. A review of mushrooms as a potential source of dietary vitamin D. Nutrients 2018, 10, 1498. [CrossRef] [PubMed]

62. Mleczek, M.; Siwulski, M.; Rzymski, P.; Budzyńska, S.; Gąsecka, M.; Kalač, P.; Niedzielski, P. Cultivation of mushrooms for production of food biofortified with lithium. Eur. Food Res. Technol. 2017, 243, 1097-1104. [CrossRef]

63. Aguilar-Rivera, N.; de Jesús Debernardi-Vázquez, T. Sustainable Development for Farmers Transforming Agroindustrial Wastes into Profitable Green Products. In Sustainable Development Research and Practice in Mexico and Selected Latin American Countries; Springer: Cham, Swizerland, 2018; pp. 53-75.

64. Istiyanti, E.; Fivintari, F.R.; Syaftiana, M. Potential development of oyster mushrooms in the lowlands of Bantul Regency, Special Region of Yogyakarta, Indonesia. In IOP Conference Series: Earth and Environmental Science; IOP Publishing: Bristol, UK, 2020; Volume 423, p. 012037.

65. Mazlan, S.Z.; Hanifah, S.A. Effects of temperature and $\mathrm{pH}$ on immobilized laccase activity in conjugated methacrylate-acrylate microspheres. Int. J. Polym. Sci. 2017, 2017, 5657271. [CrossRef]

66. Kim, K.; Kim, E.; Lee, S.J. New enzymatic time-temperature integrator (TTI) that uses laccase. J. Food Eng. 2012, 113, 118-123. [CrossRef]

67. Ghosh, P.; Ghosh, U. Statistical optimization of laccase production by Aspergillus flavus PUF5 through submerged fermentation using agro-waste as cheap substrate. Acta Biol. Szeged. 2017, 61, 25-33.

68. Zhang, R.; Wang, L.; Han, J.; Wu, J.; Li, C.; Ni, L.; Wang, Y. Improving laccase activity and stability by HKUST-1 with cofactor via one-pot encapsulation and its application for degradation of bisphenol A. J. Hazard. Mater. 2020, 383, 121130. [CrossRef] [PubMed]

69. You, S.; Zhao, Q.; Jiang, J.; Zhang, J. Treatment of domesticwastewaterwith simultaneous electricity generation in microbial fuel cell under continuous operation. Chem. Biochem. Eng. Q. 2006, 20, 407-412.

70. Igiri, B.E.; Okoduwa, S.I.; Idoko, G.O.; Akabuogu, E.P.; Adeyi, A.O.; Ejiogu, I.K. Toxicity and bioremediation of heavy metals contaminated ecosystem from tannery wastewater: A review. J. Toxicol. 2018, 2018, 2568038. [CrossRef]

71. Pardo, I.; Chanagá, X.; Vicente, A.I.; Alcalde, M.; Camarero, S. New colorimetric screening assays for the directed evolution of fungal laccases to improve the conversion of plant biomass. BMC Biotechnol. 2013, 13, 90. [CrossRef]

72. Kruger, N.J. The Bradford method for protein quantitation. In The Protein Protocols Handbook; Springer: Berlin/Heidelberg, Germany, 2009; pp. 17-24.

73. Motulsky, H.J. GraphPad Statistics Guide-Options for Multiple t Tests. 2016. Available online: http:/ / www.graphpad.com/ guides/prism/7/statistics/index.htm (accessed on 11 February 2021).

74. Fahraeus, G.; REINHAMMAR, B. Large Scale Production and Purification of Laccase from. Acta Chem. 1967, $21,2367-2378$. [CrossRef]

75. Gong, K.; Yan, Y.; Zhang, M.; Su, L.; Xiong, S.; Mao, L. Electrochemistry and electroanalytical applications of carbon nanotubes: A review. Anal. Sci. 2005, 21, 1383-1393. [CrossRef]

76. $\mathrm{Hu}, \mathrm{C}$; $\mathrm{Hu}, \mathrm{S}$. Carbon nanotube-based electrochemical sensors: Principles and applications in biomedical systems. J. Sens. 2009, 2009, 187615. [CrossRef]

77. Bishop, L.; Cena, L.; Orandle, M.; Yanamala, N.; Dahm, M.M.; Birch, M.E.; Erdely, A. In vivo toxicity assessment of occupational components of the carbon nanotube life cycle to provide context to potential health effects. ACS Nano 2017, 11, 8849-8863. [CrossRef] [PubMed]

78. Hansen, S.F.; Lennquist, A. Carbon nanotubes added to the SIN List as a nanomaterial of Very High Concern. Nat. Nanotechnol. 2020, 15, 3-4. [CrossRef] [PubMed]

79. Kostarelos, K. The long and short of carbon nanotube toxicity. Nat. Biotechnol. 2008, 26, 774-776. [CrossRef] [PubMed]

80. Wen, Z.; Ci, S.; Mao, S.; Cui, S.; Lu, G.; Yu, K.; Chen, J. TiO 2 nanoparticles-decorated carbon nanotubes for significantly improved bioelectricity generation in microbial fuel cells. J. Power Sources 2013, 234, 100-106. [CrossRef] 